\title{
A somatic component to myocardial infarction*
}

\author{
ALEXANDER S. NICHOLAS, D.O. \\ DOMENIC A. DeBIAS, Ph.D. \\ WALTER EHRENFEUCHTER, D.O. \\ KATHERINE M. ENGLAND, D.O \\ ROBERT W. ENGLAND, D.O. \\ CHARLOTTE H. GREENE, Ph.D. \\ DAVID HEILIG, D.O. \\ MICHAEL KIRSCHBAUM, D.O. \\ Philadelphia, Pennsylvania
}

\begin{abstract}
Sixty two patients were randomised to be seen by osteopathic physicians for palpation of the thoracic paravertebral soft tissue, T1-T8. Twenty five patients had clinically confirmed acute myocardial infarction. Of the remainder, 22 without known cardiovascular disease served as controls and 15 were placed in an excluded group because of diagnosed cardiovascular disease other than myocardial infarction. Observations were described in predetermined standard terminology.

The control group was found to have a low incidence of palpable changes throughout the thoracic dorsum, and these changes were uniformly distributed from T1 to T8. Examination
\end{abstract}

\author{
of the group with myocardial infarction \\ disclosed a significantly higher \\ incidence of soft tissue changes \\ (increased firmness, warmth, ropiness, \\ oedematous changes, heavy \\ musculature), confined almost entirely \\ to the upper four thoracic levels. The 15 \\ patients who were excluded from the \\ experimental group because they had \\ various cardiovascular diseases other \\ than myocardial infarction also showed \\ significantly different changes on \\ palpation compared with the group with \\ myocardial infarction. \\ These findings suggest that \\ myocardial infarction is accompanied \\ by characteristic paravertebral soft \\ tissue changes which are readily \\ detected by palpation.
}

Osteopathic medicine supports the concept that a "reflex" system of visceral and somatic interrelationships may give rise to manifestations related to disease at sites which are remote from the viscera or soma affected. ${ }^{1,2}$ These sites are referred to as the visceral or somatic "components" of the disease and appear to occur in areas of the body which are segmentally related during development. ${ }^{3}$ The visceral or somatic components in various diseases are regarded as integral parts of the pathophysiology, and as such they are detection aids in recognition and diagnosis of the disease and are therefore not ignored during the clinical management of the patient. ${ }^{4,5}$

This report presents the results of a controlled, blind study which addressed an important osteopathic principle as well as concepts which are

\footnotetext{
*Reprinted with permission from the British Medical Journal 291:13-7, 6 July 85 .
}

emphasised as fundamental to the principles and practice of osteopathic medicine.

A somatic component has often been reported in association with acute myocardial infarction. Although there are numerous reports of somatic components to disease entities, discussions of clinical observations are usually anecdotal because controlled studies to document these observations and their physiological bases are sparse. ${ }^{6,7}$ The somatic component in myocardial infarction consists of alterations in the palpable quality of the paravertebral soft tissue in the thoracic dorsum ranging from mild oedematous changes to a firmness that is resistant to palpable penetration, commonly described as a stiff, "board like" rigidity. Since myocardial infarction may be established objectively by conventional diagnostic testing, and because our participating physicians had experience with this particular observation within their practices, we decided to explore the somatic component associ- 


\begin{tabular}{|c|c|c|c|c|c|c|c|c|}
\hline \multirow[b]{2}{*}{ Group } & \multirow{2}{*}{$\begin{array}{l}\text { Age } \\
\text { (years) }\end{array}$} & \multicolumn{2}{|c|}{ Race } & \multicolumn{2}{|c|}{ Sex } & \multirow[b]{2}{*}{ Weight (kg) } & \multirow[b]{2}{*}{ Height $(\mathrm{cm})$} & \multirow[b]{2}{*}{ Diagnosis } \\
\hline & & White & Black & $\mathrm{M}$ & $\mathbf{F}$ & & & \\
\hline Control & $40-70$ & 13 & 9 & 15 & 7 & $48 \cdot 2-109 \cdot 6$ & $152 \cdot 4-190 \cdot 5$ & $\begin{array}{l}\text { Non-hospitalised volunteers }(\mathrm{n}=8) \\
\text { Hospitalised patients }(\mathrm{n}=14) \\
\text { Adenocarcinoma (right kidney): } 1 \\
\text { Chronic obstructive pulmonary disease: } 1 \\
\text { Diabetes mellitus: } 2 \\
\text { Laryngeal carcinoma: } 1 \\
\text { Posterior nasal bleed: } 1 \\
\text { Pneumonia: } 1 \\
\text { Subarachnoid haemorrhage: } 1 \\
\text { Cholecystitis: } 1 \\
\text { Hypothyroidism: } 1 \\
\text { Thrombophlebitis: } 1 \\
\text { Pancreatitis: } 1 \\
\text { Pulmonary abscess: } 1 \\
\text { Iliac artery aneurysm: } 1\end{array}$ \\
\hline $\begin{array}{l}\text { Myocardial } \\
\text { infarction }\end{array}$ & $46-94$ & 12 & 13 & 18 & 7 & $45 \cdot 5-102 \cdot 3$ & $152 \cdot 4-190 \cdot 5$ & $\begin{array}{l}\text { Anterior septal MI: } 3 \\
\text { Lateral and anterior wall MI: } 1 \\
\text { Anterior wall MI: } 12 \\
\text { Subendocardial MI: } 2 \\
\text { Inferior wall MI: } 4 \\
\text { Anterior septal MI: } 1 \\
\text { Inferior and lateral wall MI: } 1 \\
\text { Inferior and septal MI: } 1\end{array}$ \\
\hline Excluded & $35-75$ & 4 & 11 & 9 & 6 & $61-4114 \cdot 6$ & $152 \cdot 4-190 \cdot 5$ & $\begin{array}{l}\text { Aortic and mitral valve disease: } 1 \\
\text { Congestive heart failure: } 2 \\
\text { Atherosclerotic heart disease: } 4 \\
\text { Left ventricular hypertrophy: } 1 \\
\text { Uncontrolled hypertension: } 1 \\
\text { Aortic stenosis: } 1 \\
\text { Ischaemic heart disease }+ \text { arrhythmia: } 3 \\
\text { Angina pectoris: } 2\end{array}$ \\
\hline
\end{tabular}

$\overline{\mathrm{MI}}=$ Myocardial infarction.

ated with acute myocardial infarction. In conjunction with this study an animal model was developed in which histological changes in the somatic component were under investigation and the corresponding physiological mechanisms could be explored. ${ }^{6,7}$

A readily palpable somatic component would be an important sign during routine physical examination, alerting the physician to pursue a diagnosis of unrecognised myocardial infarction. Furthermore, correlating the somatic component with a specific cardiac abnormality might be valuable in assessing the efficacy of treatment by taking the rate of disappearance of the component as a reflection of improved cardiac physiology.

\section{Patients and methods}

Sixty two subjects were studied. Twenty five patients (myocardial infarction group) had had acute myocardial infarction confirmed clinically three to five days before transfer from the hospital's intensive care unit to the "step down" unit. Twenty two patients without known cardiovascular disease were selected to serve as controls and were matched as closely as possible with the patients with infarcts

\begin{tabular}{|c|c|c|c|}
\hline & $\begin{array}{l}\text { Myocardial } \\
\text { infarction } \\
\text { group }\end{array}$ & $\begin{array}{l}\text { Control } \\
\text { group }\end{array}$ & $\begin{array}{c}\text { Excluded } \\
\text { group }\end{array}$ \\
\hline Analgesics & 2 & - & 2 \\
\hline Antianginal agents & 23 & - & 15 \\
\hline Antiasthma agents & 1 & 1 & - \\
\hline Antiarrhythmic agents & 13 & - & 6 \\
\hline Antibiotics & - & 10 & - \\
\hline Anticoagulants & 1 & - & 4 \\
\hline Anticonvulsants & 1 & 1 & 1 \\
\hline Antiemetics & - & 1 & - \\
\hline Corticosteroids & - & 3 & - \\
\hline Decongestants & - & 1 & - \\
\hline Digitalis & 8 & - & 7 \\
\hline Diuretics & - & - & 4 \\
\hline Histamine $\mathrm{H}_{2}$ blockers & 一 & 3 & - \\
\hline Hypnotics & - & 6 & 3 \\
\hline Hypoglycaemic agents & 1 & 2 & 2 \\
\hline Laxatives & - & 3 & 2 \\
\hline Potassium replacement & - & 2 & 1 \\
\hline Tranquillisers & - & 2 & - \\
\hline Thyroid replacement & - & 1 & 一 \\
\hline
\end{tabular}

with regard to age, race, sex, weight, and height. A further 15 patients (excluded group) who were excluded from the two other groups because they had cardiovascular disease other than myocardial infarction were continued in the study as an ancillary group. Table I gives the clinical histories and fea- 
tures of the three groups, and table II lists the prescribed medications as recorded in the case notes.

The 62 subjects were selected at random to be examined by osteopathic physicians, who were kept unaware of their diagnoses. All examinations were performed in the step down unit. The physicians were constrained to confine examination to palpating the paravertebral soft tissue of the thoracic dorsum, and their descriptions were limited to predetermined standardized terminology (fig 1). Any conversation with the subject that might provide "judgment" clues was prohibited. Visual clues (simulated in controls) such as monitors, gowns, iden-

PATIENT RECORD No

\begin{tabular}{|c|l|l|l|l|l|l|l|}
\hline $\begin{array}{c}\text { PALPATION } \\
\text { DATE }\end{array}$ & SEX & AGE & HEIGHT & WEIGHT & RACE & $\begin{array}{c}\text { ELAPSED TIME } \\
\text { FROM DATE OF } \\
\text { ADMISSION }\end{array}$ & TREATMENT/MEDICATION \\
\hline & & & & & & & \\
\hline
\end{tabular}

PARAVERTEBRAL THORACIC SPINE

\begin{tabular}{|c|c|c|}
\hline LEFT & LEVEL & RIGHT \\
\hline & T1 & \\
\hline & T2 & \\
\hline & T3 & \\
\hline & T4 & \\
\hline & T5 & \\
\hline & T6 & \\
\hline & T7 & \\
\hline & T8 & \\
\hline
\end{tabular}

PLACE DESCRIPTIVE CODE IN APPROPRIATE LOCATION ON THORACIC SCHEMA, INDICATE SUPERFICIAL OR DEEP BY THE SUBSCRIPT 1 OR 2 RESPECTIVELY

\begin{tabular}{|l|l|}
\hline CODE & \multicolumn{1}{|c|}{ TERM AND DEFINITION } \\
\hline A & Tense, firm, resistant \\
\hline B & Friction \\
\hline C & Slick \\
\hline D & Boggy, doughy \\
\hline E & Flaccid, atrophic \\
\hline F & Spasticity \\
\hline G & Fullness \\
\hline Hm & Heavy musculature, increased density \\
\hline R & Ropiness, "cord like" \\
\hline S & Stringiness, "fibre like" \\
\hline Sh & Shottiness, "beadlike," "pellet like" \\
\hline CC & Colour change \\
\hline TC & Temperature cold \\
\hline TW & Temperature warm \\
\hline X & Dry \\
\hline Y & Moist \\
\hline Z & Normal \\
\hline
\end{tabular}

Fig. 1. Record sheet used by examining osteopathic physician. Demographic details were entered by technician after palpation was completed. 
tity bracelets, intravenous lines, and chart covers were identical in every case.

The subjects were examined privately, in the presence of a technical assistant, by one of the five participating osteopathic physicians, selected at random. The data derived from each subject were compiled and coded using computerized data processing techniques. On completion of the study the code was broken and statistical evaluations performed using Fisher's exact probability test. Probability (p) values of 0.05 or less were considered statistically significant.

Written, informed consent to the study was obtained from all subjects, and the study was approved by the American Osteopathic Association Bureau of Research and the Institutional Review Board of the Philadelphia College of Osteopathic Medicine.

\section{Results}

Analysis of the responses made by the physicians after examination confirmed that there were significant differences among the three groups. The 25 subjects with myocardial infarction showed a high incidence $(67 \%)$ of altered sites along T1-T8 on the left - that is, 134 altered sites out of a possible 200 ( 8 thoracic sites $\times 25$ patients). The altered sites were primarily confined to the left upper four thoracic segments (fig 2). Statistically significant differences were found at $\mathrm{T} 1$ to $\mathrm{T} 4$ on the left and at T4 on the right when the thoracic levels in subjects with myocardial infarction were compared with the corresponding sites in the controls (table III).

The 22 control subjects, who were free of detectable heart disease, were found to have a low incidence of palpable alterations at each of the eight

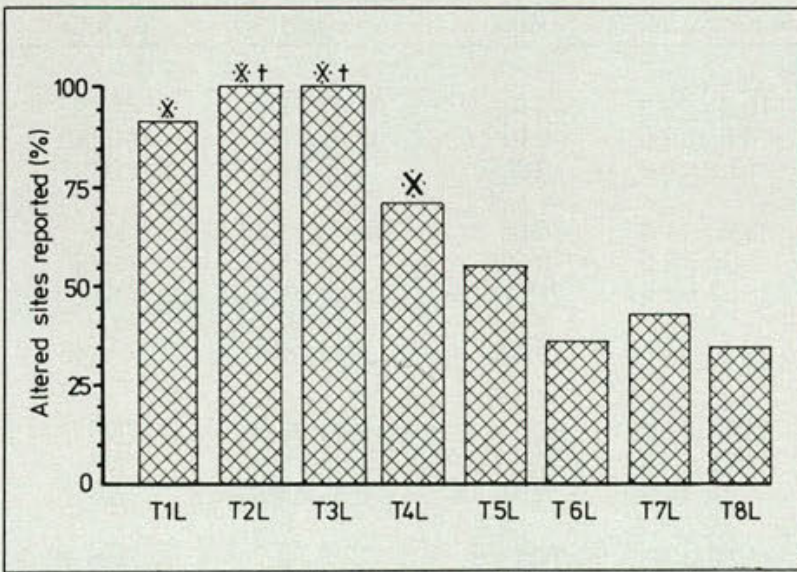

Fig. 2. Incidence of all descriptors used during palpation of 25 subjects with myocardial infarction. Results presented as percentage of total responses possible for all descriptors. (Thoracic dorsum T1-T8 left.)

*Significantly different from controls.

† Significantly different from excluded subjects. thoracic levels examined (T1-T8, right and left). Out of a possible 176 opportunities on the left side, only 59 altered sites were recorded ( $29 \%$ incidence); moreover, these sites were scattered throughout T1T8 rather than clustered at any specific level (fig 3 ).

In the excluded subjects with heart disease other than myocardial infarction the incidence of altered sites on the left was higher than in the controls but not as high as in the subjects with myocardial infarction (fig 4). Out of a possible 120 opportunities, 78 sites were recorded ( $65 \%$ incidence). Table III illustrates the important difference. In the excluded group the altered sites were more confined to T1-T4 than in the controls and more widely distributed than in the group with myocardial infarction. Also, the segmental pattern of distribution for the excluded group resembled that for the subjects with myocardial infarction with the exception of $\mathrm{T} 4$ on the right.

\begin{tabular}{|c|c|c|c|c|c|c|}
\hline \multirow[b]{2}{*}{$\begin{array}{l}\text { Thoracic } \\
\text { level }\end{array}$} & \multicolumn{2}{|c|}{$\begin{array}{c}\text { Myocardial } \\
\text { infarction } \\
v \text { control }\end{array}$} & \multicolumn{2}{|c|}{$\begin{array}{c}\text { Control } \\
v \text { excluded }\end{array}$} & \multicolumn{2}{|c|}{$\begin{array}{c}\text { Myocardial } \\
\text { infarction } \\
v \text { excluded }\end{array}$} \\
\hline & $\begin{array}{l}\text { Left } \\
\text { side }\end{array}$ & $\begin{array}{l}\text { Right } \\
\text { side }\end{array}$ & $\begin{array}{l}\text { Left } \\
\text { side }\end{array}$ & $\begin{array}{c}\text { Right } \\
\text { side }\end{array}$ & $\begin{array}{l}\text { Left } \\
\text { side }\end{array}$ & $\begin{array}{l}\text { Right } \\
\text { side }\end{array}$ \\
\hline $\mathrm{T} 1$ & $\mathrm{p}<0.001$ & NS & $\mathrm{p}<0.01$ & NS & NS & NS \\
\hline $\mathrm{T} 2$ & $\mathrm{p}<0.001$ & NS & $\mathrm{p}<0.05$ & NS & $\mathrm{p}<0.05$ & NS \\
\hline T3 & $\mathrm{p}<0.001$ & NS & $p<0.05$ & NS & $\mathrm{p}<0.05$ & NS \\
\hline T4 & $\mathrm{p}<0.001$ & $p<0.01$ & NS & NS & NS & NS \\
\hline T5 & NS & NS & NS & NS & NS & NS \\
\hline T6 & NS & NS & NS & NS & NS & NS \\
\hline T7 & NS & NS & NS & NS & NS & NS \\
\hline T8 & NS & NS & NS & NS & NS & NS \\
\hline
\end{tabular}

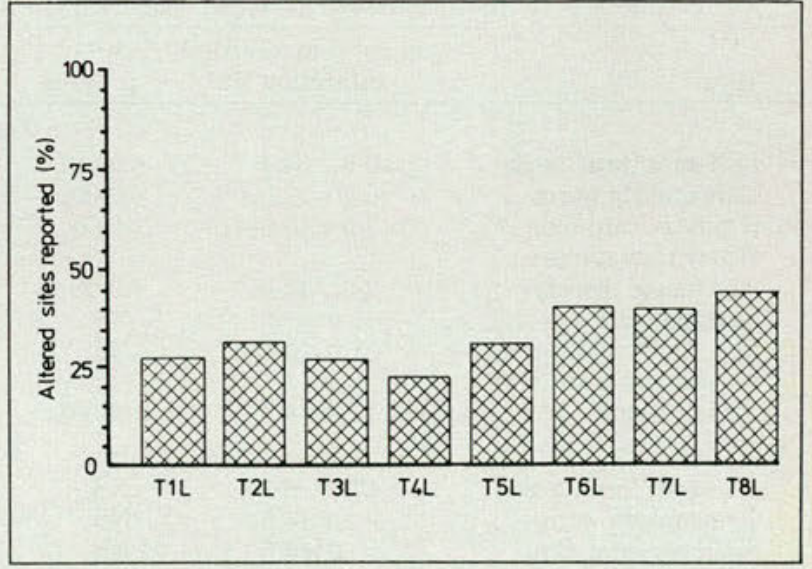

Fig. 3. Incidence of all descriptors used during palpation of 22 control subjects. Results presented as percentage of total responses possible for all descriptors. (Control group derived in part from hospital admissions for complaints other than myocardial infarction or cardiovascular, and in part from non-hospitalised volunteers; conceivably somatic expression of other visceral diseases may have contributed to altered sites in these subjects.) (Thoracic dorsum T1-T8 left.) 
Comparative analysis of the descriptor terminology showed significant differences in the frequency of usage within the three groups (table IV). In the group with myocardial infarction firmness and warm temperature were the most frequently noted $(34.4 \%$ and $32.0 \%)$, followed by heavy musculature $(13.6 \%)$ and ropiness $(13.0 \%)$. In the excluded group firmness was the most frequent soft tissue alteration $(29.5 \%)$, followed by warm temperature $(18.0 \%)$, heavy musculature $(11.5 \%)$, and oedematous $(8.2 \%)$. The most frequent observation in the control group was "normal" $(77.3 \%)$, followed by firmness at only $10.3 \%$.

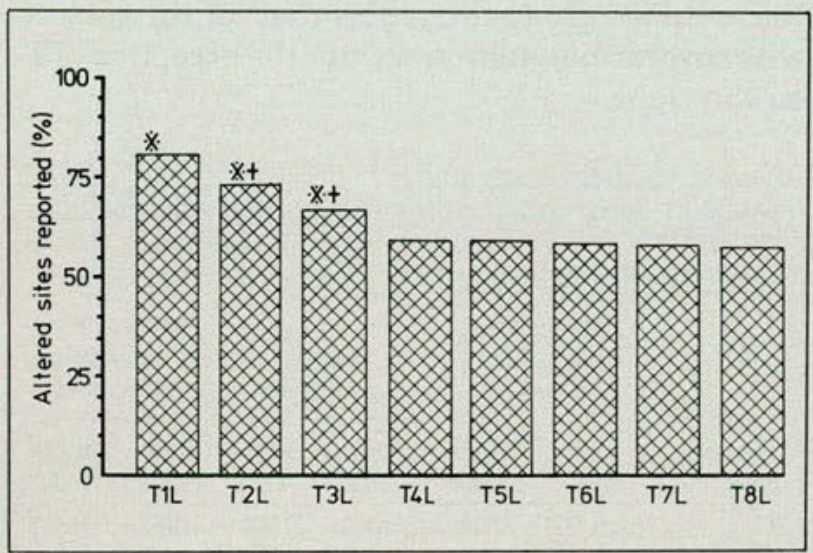

Fig. 4. Incidence of all descriptors used during palpation of 15 excluded subjects. Results presented as percentage of total responses possible for all descriptors. (Thoracic dorsum T1-T8 left.)

*Significantly different from controls.

†Significantly different from subjects with myocardial infarction.

\begin{tabular}{|c|c|c|c|c|c|c|}
\hline Term & $\begin{array}{c}\text { Control } v \text { myocardial } \\
\text { infarction }(\%)\end{array}$ & p Value & Control $v$ excluded (\%) & p Value & $\begin{array}{c}\text { Myocardial infarction } \\
v \text { excluded }(\%)\end{array}$ & p Value \\
\hline \multicolumn{7}{|c|}{ T1-T4 left } \\
\hline Resistant (firm, tense) & $10 \cdot 3 v 34.4$ & $<0.001$ & $10 \cdot 3 v 29.5$ & $<0.01$ & $34.4 v 29.5$ & $<0.01$ \\
\hline Temperature warm & $6.5 v 32.0$ & $<0.001$ & $6.5 v 18.0$ & $<0.01$ & $32.0 v 18.0$ & $<0.001$ \\
\hline Ropiness (cord like) & $3.6 v 13.0$ & $<0.001$ & $3.6 v 3.3$ & NS & $13.0 v 3.3$ & $<0.01$ \\
\hline Heavy musculature & & & & & & \\
\hline (increased density) & $3.0 v 13.6$ & $<0.001$ & $3.0 v 11.5$ & $<0.05$ & $13.6 v 11.5$ & NS \\
\hline Oedematous & $1.0 v 1.2$ & NS & $1.0 v 8.2$ & $<0.02$ & $1.2 v 8.2$ & $<0.05$ \\
\hline Dry & $1.0 v 3.2$ & NS & $1.0 v 0$ & NS & $3 \cdot 2 v 0$ & NS \\
\hline $\begin{array}{l}\text { Normal (no unusual } \\
\text { observations) }\end{array}$ & $77 \cdot 3 v 8 \cdot 1$ & $<0.001$ & 4 right & $<0.001$ & $8 \cdot 1 v 29 \cdot 5$ & $<0.05$ \\
\hline Resistant (firm, tense) & $13 \cdot 6 v 8 \cdot 1$ & NS & $13.6 v 11.0$ & NS & $8.1 v 11.0$ & NS \\
\hline Temperature warm & $9 \cdot 1 v 14.5$ & NS & $9 \cdot 1 \cup 7 \cdot 4$ & NS & $14.5 \cup 7 \cdot 4$ & NS \\
\hline Ropiness (cord like) & $0 v 6.5$ & NS & $0 v 14 \cdot 8$ & $<0.01$ & $6.5 v 14 \cdot 8$ & NS \\
\hline Heavy musculature & & & & & & \\
\hline $\begin{array}{l}\text { (increased density) } \\
\text { Oedematous }\end{array}$ & $\begin{array}{r}4 \cdot 6 \cup 12 \cdot 9 \\
9 \cdot 1 v 3 \cdot 2\end{array}$ & $\begin{array}{l}\text { NS } \\
\text { NS }\end{array}$ & $\begin{array}{l}4 \cdot 6 v 3 \cdot 7 \\
9 \cdot 1 \cup 7 \cdot 4\end{array}$ & $\begin{array}{l}\text { NS } \\
\text { NS }\end{array}$ & $\begin{array}{r}12.9 v 3.7 \\
3.2 v 7 \cdot 4\end{array}$ & $\begin{array}{l}\text { NS } \\
\text { NS }\end{array}$ \\
\hline Dry & $\begin{array}{rl}0 & v 3.2\end{array}$ & NS & $0 v 0$ & NS & $3.2 v 0$ & NS \\
\hline $\begin{array}{l}\text { Normal (no unusual } \\
\text { observations) }\end{array}$ & $63.6 v 48 \cdot 4$ & $<0.05$ & $63 \cdot 6 v 44 \cdot 4$ & NS & $48 \cdot 4 v 44 \cdot 4$ & NS \\
\hline
\end{tabular}

\section{Discussion}

Qualitative somatic tissue changes in subjects with documented myocardial infarction have been shown to be discrete and readily palpable. There has been much discussion within the osteopathic profession concerning the role of the sympathetic nervous system as a mediator in such phenomena. This hypothesis is based on the similar embryological origin of the innervation to somatic and visceral tissue ${ }^{8}$ In the case of the heart the cardiac plexus of nerves is composed of branches from the cervical sympathetic ganglia and the upper seven thoracic ganglia. About twice as many fibres enter the cardiac plexus from the thoracic nerves as enter from the cervical cardiac nerves. ${ }^{9}$ Changes in soft tissue in patients with cardiac disturbances were found most often on the thoracic dorsum..$^{10,11}$ It is plausible to attribute their aetiology to efferent and afferent reflex activity during the evolution of myocardial infarction. This activity may, by way of visceral afferents, constitute an arc through the related spinal cord levels which might be manifested over the posterior spinal nerves as somatic foci of irritation. Those qualitative descriptors used in this study which reflect autonomic activity indicated that the alterations in tissue which occurred may be associated with changes in autonomic tone.

The non-invasive nature of the examination protocol precluded accurate definition of the specific histological alterations related to the various terminology that was selected. Identification of the histological changes within these areas is cur- 
rently under study in a canine model, in which sublethal myocardial infarction is induced by placement of microspheres via a catheter into the coronary arteries with the aid of image intensification fluoroscopy. ${ }^{6,7}$ The sites of palpable tissue changes have been biopsied and subjected to electron microscopy and morphometric analyses. This companion study will be reported on completion of these analyses.

Cardiovascular disease, as represented by our exclusion group, is a heterogeneous mixture of disorders. Inclusion of this mixture in a single group for analysis precludes delineating a somatic component for each of the disorders. Although the incidence of altered sites was significantly higher in this group than in the controls, it was significantly less than in the subjects with myocardial infarction. Also the observations were more widely distributed along the thoracic dorsum. The medications, listed in table II, consisted primarily of antianginal, vasodilatory, and antiarrhythmic agents. The effects of these drugs on viscerosomatic reflexes have not been specifically studied to date.

The design of this study did not permit evaluation of interexaminer agreement-that is, each subject was examined by only one of the five physicians, selected at random. Interexaminer agreement, however, was evaluated in the canine study.

Of 30 beagle type mongrel dogs used in the study, 23 (eight infarcted, seven sham, eight controls) were examined by more than one osteopathic physician. The dogs were chosen by a random numbers technique for daily examination, the physicians being blindfolded throughout to prevent visual clues and recognition of the animals. The physicians confined palpation to the soft tissue of the dorsal aspect (depilated) of the thorax (T1-T13). Descriptions of their observations were limited to predetermined standardised terminology. Each examining physician was unaware of the other's participation, so that data were available for evaluation of interexaminer agreements. Two examiners who participated in the experimental study also served as examiners for the clinical study (AN and $\mathrm{DH}$ ). The observations on each animal were grouped by thoracic zones rather than by each of the 13 segments $-\mathrm{Z} 1=\mathrm{T} 1$ and $\mathrm{T} 2 ; \mathrm{Z} 2=\mathrm{T} 3-\mathrm{T} 10 ; \mathrm{Z} 3$ $=\mathrm{T} 11-\mathrm{T} 13$ - since we expected that discrimination of the soft tissue by palpation would not exceed \pm 1 spinal segment in the canine model. Observations were recorded as either "normal" or "altered" for evaluating interexaminer agreement (fig 5). $\chi^{2}$ Analysis with Yates's correction showed agreement between examiners for each of the 23 dogs in zone 1 , right and left. In zone 2, right and left, there was significant disagreement for eight dogs out of 23 on

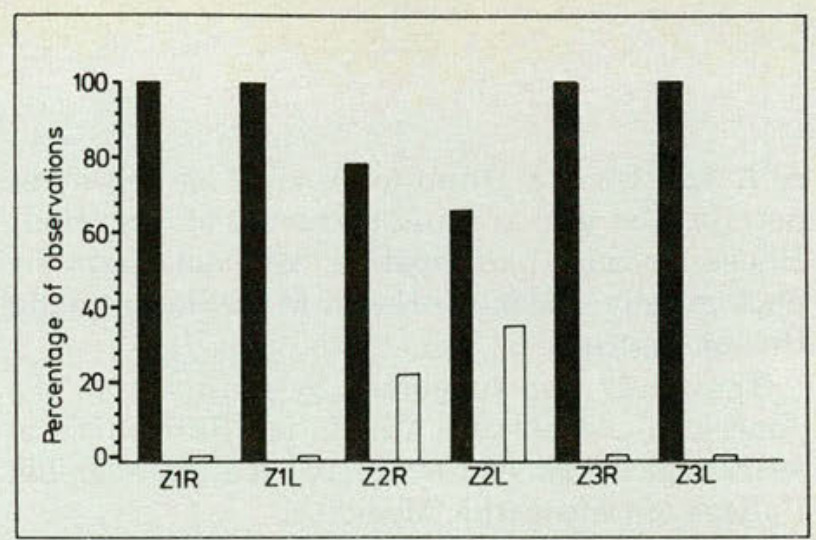

Fig. 5. Interexaminer agreements (solid columns) and disagreements (open columns). Results presented as percentage of total responses for each zone (Z) for all 23 dogs. (Thoracic dorsum right and left.)

the left side and for five dogs out of 23 on the right. In zone 3 there was agreement for all 23 dogs.

Further to investigate the extent of bias inherent in the palpation, disagreements were analysed by McNemar's corner test. ${ }^{12}$ Theoretically, if one examiner is equivalent to the other, then disagreement (normal/altered) between them should ideally be distributed 50:50 - that is, for each time one examiner observes "normal" the other would observe "altered." Bias was not detected significantly in six of the 13 zones where there were interexaminer disagreements, while seven of the 13 disagreements showed significant bias. There was good evidence of interexaminer agreement, since bias was shown in only seven of 13 disagreements and significant interexaminer disgreements occurred in only 13 out of a total of 138 sites ( 3 zones (right and left) $\times 23$ ) in the 23 animals examined.

We have established that somatic changes in the thoracic dorsum can be detected by routine palpation of soft tissue in patients with acute myocardial infarction. These observations may provide the physician with a simple bedside manoeuvre to aid in diagnosing an acute myocardial infarction or predicting an impending myocardial infarction. Further investigation is required to define the anatomy of the sympathetic reflex arc and also to delineate palpable changes found in cardiovascular diseases other than acute myocardial infarction.

We are grateful to the nursing staff in the step down unit of the intensive care unit for their cooperation; Dr Hyman Menduke, Jefferson Medical College, for advice on statistical analyses; Ms Maria V Arbizo for coordinating the technical aspects of the study and designing computer programs; Ms Wanda L Young for computer generated graphics; Mr Dennis A DeBias, Ms Dorothy H Dris- 
coll, and Dr Jon Oline for reviewing the manuscript; the director and residents of Overmont House for their participation; Mr Paul Harm for photography; and Ms Christine M Cirillo for typing the manuscript.

The study was supported by grants from the American Osteopathic Association Bureau of Research (grant No 81-10-036) and the Philadelphia College of Osteopathic Medicine.

\footnotetext{
1. Denslow, J.S.: Pathophysiologic evidence for the osteopathic lesion. In: Goldstein, M.M., ed. The research status of spinal manipulative therapy. Bethesda, Md: U.S. Department of Health, Education, and Welfare, pp. $227-33,1975$

2. Eble, J.N.: Somatic manifestations of experimental visceral disturbances. Journal of Osteopathy 65:13-6, 1958

3. Rumney, I.C.: The relevance of somatic dysfunction. J Am Osteopath Assoc 74:723-5, 1975

4. Hitchcock, M.E.: Myocardial considerations in the thoracic area. Osteopathic Medicine 3:85-94, 1978

5. Tilley, R.M.: The somatic component in heart disease. Osteopathic Annals 2:30-7, 1974

6. Debias, D.A., Greene, C.H., Heilig, D., Micholas, A.S., and Harrer, W.: A somatic component to experimental myocardial infarction. Physiologist 23:118, 1980

7. DeBias, D.A., Greene, C.H., Heilig, D., Nicholas, A.S., and Harrer,
}

W.V.: A somatic component to experimental myocardial infarction. J Am Osteopath Assoc 2:139, 1982

8. Cole, W. V:: A reflex basis for osteopathic medicine. J Am Osteopath Assoc 63:343-50, 1963

9. Cathie, A.G.: Some anatomicophysiologic aspects of vascular and visceral disturbances with special references to cardiac disease. Yearbook of the Academy of Applied Osteopathy, pp. 92-7, 1965

10. Koch, R.S.: The spinal component in heart disease. Yearbook of the Academy of Applied Osteopathy, pp. 67-72, 1957

11. Patriquin, D.A.: Osteopathic management of coronary disease. Yearbook of the Academy of Applied Osteopathy, pp. 75-80, 1957

12. McNemar, Q.: Psychological statistics. London: John Wiley and Sons, pp. $54-63,1969$

From the Philadelphia College of Osteopathic Medicine, Philadelphia, Pennsylvania, where Dr. Nicholas is associate professor of osteopathic principles and practice; Dr. DeBias is professor of physiology and pharmacology, and Chairman and Assistant Dean for basic sciences; Dr. Ehrenfeuchter is assistant professor of osteopathic principles and practice; Dr. K. England is associate professor of osteopathic principles and practice; Dr. R. England is Dean and professor of anatomy and osteopathic principles and practice; Dr. Greene is associate professor of physiology; Dr. Heilig is professor of osteopathic principles and practice, and Vice Chairman, Department of Osteopathic Principles and Practice; and Dr. Kirschbaum is assistant professor of internal medicine, and Chairman, Division of Cardiology.

Dr. DeBias, Department of Physiology and Pharmacology, Philadelphia College of Osteopathic Medicine, 4150 City Avenue, Philadelphia, Pennsylvania 19131 